\title{
3 \\ PS intra-party politics and party system change
}

\author{
Ben Clift
}

\section{Introduction}

Approaches to the study of party system change tend to emphasise, on the one hand, broad electoral trends, such as disaffection with 'governmental' political parties, or increasing electoral volatility and, on the other, institutional developments, such as changes to voting systems. Such 'macro'-level analysis can at times treat parties as unitary actors, possessed of one 'response' to their changing environment, an approach which underplays analysis of the party itself. This chapter offers a two-tier analysis of the interaction between developments within the party system as a whole, and the internal politics of the French PS.

At both levels, an appreciation of both structure and agency is vital to understanding how both the PS and the party system have recently evolved. The first section illustrates the institutional constraints of the French party system, and how its competitive demands helped to structure the internal organisation of the PS. Subsequent sections show how, in turn, the PS has shaped the development of the French party system. The French party system is not a particularly rigid structure, destabilised by numerous changes to the electoral 'rules of the game', changing patterns of voting behaviour, and changing constituent parties over the last twenty years. As for agency, the set of actors shaping electoral strategy within a party can change rapidly. Furthermore, the internal organisational rules governing internal power relationships are themselves prone to evolve, affecting to what extent one particular strategic vision can achieve ascendancy within the party, and beyond it.

Disaggregating beyond the level of the party, and the party's response to a changing environment involves two dimensions. First, party disaggregation involves analysing different strategies from different factional groupings within the party. This leads in turn to considering a set of 
intra-party structure and agency relationships in order to understand how factional interaction is mediated by the internal organisation of the party. Understanding these relationships is important, since which set of perceptions are in the ascendant within a party crucially affects the interaction with the party system and relations between competitor parties. The role of internal developments, as either a barrier or a precondition to the emergence of a more coherent electoral strategy in the late 1990s, is illustrated below.

Second, parties must be treated as independent variables, which actively interact with and constitute the party system. This is because political strategy involves both which competitor formations should the PS seek to ally with (and what should be the nature of those allegiance arrangements) and how the PS should seek to restructure the electoral system, thus reshaping the balance of forces within the French party system. This chapter considers how PS factionalism and organisational changes structure the internal debate, and shape the PS approach to the two dimensions of political strategy. The final section examines a series of significant episodes in the PS's development in the 1990s and explores the processes of interaction between intra-party politics and opportunities for party system change.

\section{The French party system, the logic of rassemblement, and the union de gauche}

The advent of the Fifth Republic brought with it a new electoral system for presidential and legislative elections, specifically designed to preclude the perceived systemic weaknesses of the Fourth Republic. The two-ballot majoritarian system contained institutional constraints requiring parties to reach a 12.5 per cent ${ }^{1}$ threshold in the first ballot of parliamentary elections, and the rule that only two candidates progress to the second ballot of presidential elections. These presented a hurdle to smaller parties, and unleashed systemic incentives for larger parties, in the second ballot, to gain votes transferred from those eliminated after the first. The majoritarian two-ballot system thus favours both alliance candidates from the first ballot, and agreements of the weaker candidate to stand down between the two ballots.

At the same time, the extraordinary 'catch-all' success of the Gaullist Union pour la Nouvelle République (UNR) (Kirchheimer 1990: 54-5) encompassed most of the right, but extended into the centre and even to elements of the working-class left electorate. This is a case of Kirchheimer's catch-all thesis skewed by de Gaulle's success within a bi-polar presidentialised party system. Mitterrand appreciated the need to exploit the possibilities of discipline républicaine - or the need for a transfer of 
votes from other left groupings to the most likely winner between the two rounds. To this end, ideological distance from the PCF had to be reduced in a party system bipolarised by Gaullism. There was thus none of Kirchheimer's 'de-ideologization' and no 'drastic reduction in the party's ideological baggage' (1990: 58). On the contrary, there was a reaffirmed turn to the left.

Appreciation of these systemic factors lay at the heart of Mitterrand's strategic vision. Arguably, the reconfiguration of the left culminating at Epinay in 1971 was designed almost purely to exploit electoral opportunities of the Fifth Republic. As Hanley notes, 'the whole enterprise of creating the successful post-1972 PS stemmed from realising what the new electoral system involved ... a new-look Socialist party had to be put together out of the SFIO and the oddments of the "non-communist Left", (1999a: 61). Bergounioux and Grunberg note that the PS is "more a juxtaposition of courants, traditions, and personalities than a genuinely unified party' (1992: 293). This federating process, however imperfect, was a necessary precondition of the union de gauche - the marriage of convenience which formed the linchpin of Mitterrand's strategy. The centrifugal tendencies of the French left endured (Bartolini, 1984, Bell, Chapter 2 of this volume), but such countervailing institutional constraints often overwhelmed such tendencies.

Thus the make-up of the PS bore the imprint of the functional requirements of the Party system. Internal proportional representation and the factionalism it institutionalised was also functional to the process of rassemblement required by the electoral system, enabling the PS to broaden its catchment area and bring together a more diverse electorate at the second ballot than would be possible, for example, with the monotheism of the PCF. Indeed, Sferza and Lewis (1987) argue that PS factionalism in large part explains the advances made in the 1970s. Schlesinger and Schlesinger's recent study attests to the effectiveness of the aspect of the PS as an electoral machine (2000: 142, table).

\section{The competing institutional and electoral logics of the French party system}

French political life involves many different electoral systems, electing the numerous representative bodies within the French polity. Elections, according to Machin, 'are too numerous and frequent, different electoral systems encourage different and sometimes conflicting competitive strategies and electoral systems are often changed' (1989: 76). Different electoral rules in effect demand conflicting electoral strategies. In order to assess whether a party designed to operate under the second-ballot rassemblement logic of the 1970 s successfully adapted to the competing 
proportional and majoritarian logics at various levels, we should first briefly outline the significant changes.

'Decisive' presidential and parliamentary elections remain majoritarian penalising small parties, and encouraging the formation of coalitions. 'Intermediary' elections, however, have become increasingly proportional, encouraging parties to stand up and be counted. First, proportional European elections were instituted in 1979, with a 5 per cent threshold, and the country treated as one constituency. Second, in 1982, municipal elections became semi-proportional with 50 per cent of the seats awarded to the majority (or plurality) in the second ballot, but with the other 50 per cent of seats shared in proportion to votes cast. Third, at the time of the one-off proportional parliamentary elections in 1986, the first elections of the regional councils took place, 96 departments became multi-member constituencies, with a 5 per cent threshold, and seats distributed on the 'highest average principle' (Machin, 1989: 75).

This external turbulence of changing rules of the game in the party system coincided with a (slightly) calmer internal atmosphere within the PS as a result of Mitterrand's unchallenged supremacy until 1988. This ensured that his strategic vision prevailed. Although genetically programmed to operate under a majoritarian system inducing rassemblement in the second ballot, the PS proved adept at pursuing other strategies for different kinds of elections. This was facilitated by the party's flexibility, a by-product of its 'weakness' - the party has comparatively low membership, a small bureaucratised national office, and a tradition of local autonomy. For example, differential candidate selection procedures within the PS afford different degrees of influence to the national and local organisations. ${ }^{2}$

Part-cause and part-effect of the flexibility and 'weakness' of the PS is the hold that local notables - what Mény calls the 'Republican aristocracy' (1995) - have over the national party organisation. This tradition of local autonomy is highly significant in terms of electoral alliances, given the differential local performance of some of the PS's allies. An established notable, taking account of the relative strength of potential electoral allies in his or her locality, will decide the appropriate strategy accordingly, with scant regard for national strategic directives to the contrary.

Such localised strategic variation means that few generalisations can be made about national electoral strategy, since it varies in accordance with local electoral realities. Here again, the importance of developments within PS factionalism are significant. At the height of the factional skirmishing in the late 1980s and early 1990s, coordination was difficult to achieve. This was because of geographical variations in the strength of support for a particular faction. Certain federations operate as power bases for particular factions, and thus in an area where one faction predominates, it was difficult to impose a strategy too closely associated with a factional rival. 
As the strategic context of PS electoral strategy became more complex, with the range of and variation in strategic options increasing, such organisational malleability enabled the PS to reconcile divergent positions. These are variations which the national organisation has neither the ability, nor perhaps the inclination, to counter. This organisational flexibility was thus a pressure valve releasing some of the tensions caused by the competing logics of the various electoral systems.

Lastly, in the last twenty years, the public opinion climate in France has been characterised by a crisis of representation for governmental parties, evidenced by electoral trends towards 'protest' voting, abstention and increased volatility (Boy and Mayer, 1997). The coincidence of disaffection with the political system, and the governmental parties within it, and with the electoral system changes outlined above is significant. None of the larger parties (PS, RPR or UDF) has sustained claims to 'catch-all' party status (Kirchheimer, 1990), in part because smaller parties benefited from protest voting. Proportional representation greatly increased the effectiveness of such expressions of disaffection. Furthermore, even in majoritarian elections, the impact of volatility has been significant, with no incumbent government having won a legislative election since 1978 - the so-called hyper-alternance (Evans and Ivaldi, 2002).

That said, we have not seen the triumph of smaller parties over governmental parties. The PS, even in its darkest electoral hour, still received more support than any other left political grouping. While the hegemony of the governmental parties has receded in the face of increasing volatility and abstention, the smaller parties have no more than dented large party support, unable to make the advances that some analysts predicted for them. In this situation, the PS cannot succeed alone, but remains the most important single left grouping. The need for electoral allies is clear. As Charlot puts it, 'this combining of forces between forces necessarily close at the level of ideas and political interests ... finds its cement in the institutional constraints which make the abandonment of union politically costly' (1992: 23). Thus for all the evolutions, continuity in decisive elections means a familiar logic continues to structure the party system.

\section{PS factionalism - structuring the debate over political strategy}

Parties are not unitary actors. They should be treated more as arenas, incorporating competing groups of actors, and a number of competing strategies in the face of a given structural context, as well as different suggestions for reform to that context. Intra-party differences over how to play the hand dealt by the strategic context of the French party system, 
and what structural changes to the system would further the party's ends, must be taken into account. This necessitates unearthing the intra-party political mechanisms, particularly pressing in the study of the PS where internal proportionality institutionalising 'presidentialised factionalism' has structured the party's development since its foundation at Epinay (Bell and Criddle, 1988, 1994, Cole, 1989).

Hine's framework for the analysis of party factionalism identifies structural incentives to factionalism. Following Sartori (1976: 94-104), Hine places considerable emphasis on the role of internal PR, arguing that, 'the use of proportionalism can have an important impact on the nature of intra-party conflict and, when introduced, can make actions more rigid and draw more individuals into their ambit' (1982: 45). It has been argued elsewhere that the importance of these structural incentives to factionalism has been overstated (Cole, 1986, 1989, Clift, 2000). This point is best illustrated by charting the fluctuating levels and intensity of factionalism within the PS since 1971. There were periods of very intense factional infighting, notably 1978-80 (Cole, 1989) and 1988-1992 (Dupin, 1991, Clift, 2000) which were interspersed with relatively calmer periods. Such fluctuation leads us to search for other factors influencing factionalism, since the system of $\mathrm{PR}$, in operation throughout, cannot explain the variation.

Focusing almost exclusively on internal proportional representation tends to crowd out analysis of conjunctural incentives to factionalism, linked to different strategies pursued by factions depending on the political context. This political context is affected by such variables as the proximity of elections, and whether the leader has achieved internal hegemony within the party. Equally, it will be affected by changes in relations with competitor parties, and perceived opportunities for changes in electoral strategy. The set of non-structural incentives to PS factionalism considered here are the differences between factional camps of strategy and tactics both over what changes to the institutional parameters of party system should be advocated, and how to play the hand dealt the PS by the French party system and electoral context.

Electoral strategy is a key battleground of factional struggle. For example, one reading of the 'two cultures' thesis sees the fundamental schism within French Socialism as not a philosophical battle pitting Bernstein against Kautsky, but a purely strategic divergence over whether or not the PCF constitute appropriate electoral allies. The broad outlines of the two dominant strategic choices have remained constant, that is either ouverture towards the centre, or Union towards the left, and including the Communists. In 1985, the split between Rocard and Mitterrand centred on PR, with Rocard resigning in objection to Mitterrand's relatively (but not entirely) successful electoral manipulation of the 1986 elections. Criticism and counter-criticism of these competing strategies, 
and such electoral engineering, continued to dominate discussion of electoral strategy in the post-Mitterrand era.

Internal disagreement passed through the channels of the courants, which shaped the debate and limited the range of options. As we saw, the party's structure facilitated the uniting of the diverse groups behind the left's présidentiable. At the same time, however, each of the factions was afforded the luxury of their own présidentiable who could fight his or her faction's doctrinal corner, play a prominent role in internal party life, and in the longer term could groom themselves and position themselves as Mitterrand's heir apparent. Each courant leader - or 'elephant' as they are not-so-affectionately called in the party - must be the first signatory to their courant's motion or general political statement (containing clues as to their electoral strategy position) which is presented at a conference. ${ }^{3}$

Courants, the received wisdom goes, are a positive and enlivening element of internal debate when they bring forth new ideas and engage in debates. However, those tasks, which were performed admirably in the 1970s have been superseded. In the mid to late 1980s, courants with their own finances, offices, and newspapers, behaved increasingly like parties within a party. The title 'courant de pensée' became decreasingly appropriate as the doctrinal role diminished, leaving only the organisational, power-brokering role. Rennes, the apogee of the courant system as a gladitorial power struggle, made this drift all the more apparent. There ensued, in the years after the Rennes Congress, a sea change in the approach to internal pluralism, with a shift away from formal organisation along the 'parties within parties' lines, and towards Rose's 'stable sets of attitudes' model (1964). This has been accompanied by institutional changes, reducing the reliance on internal proportionality, and a revived convention of synthesising the major positions before congress, with all the major groupings effectively forming one courant (Clift, 2000). These internal changes, which ultimately underpinned Jospin's internal hegemony (see below), were accompanied by changes in the PS's electoral context, presenting some novel strategic challenges.

\section{Episode 1: 'New politics', new cleavage formation?}

In the later 1980s and early 1990s, support for political ecologism in France (the principal formations being Génération Ecologie (GE) and les Verts - the Greens) increased dramatically. After a 10 per cent showing in the 1989 European elections, the Greens polled 15 per cent of votes cast in the regional elections of 1992. The fact that one polling institution put ecologist support at 19 per cent in January 1993 did little to dampen ecologist hopes (Boy, 1993:161). In the context of the declining electoral fortunes of the PS and adverse public opinion, a factional debate between Mauroy (First Secretary from 1988 to 1992) and Fabius (First Secretary 
after Mauroy's resignation in 1992) centred on how to approach this new political formation.

The debate had two dimensions. On the one hand, it concerned contingent relations between the two parties, involving traditional debates about whether to sign non-aggression pacts, to agree not to stand in certain seats, or désistement between ballots in favour of the best-placed first-round candidate. On the other hand, there were debates about what structural changes to the French party system the PS might advocate either as carrots to encourage the ecologists to the negotiating table, or in the party's own interest. If the various forces of French political ecologism could be shepherded under the same umbrella as the PS, the speculation went, then this might represent a sufficiently powerful electoral force to keep the right out of power for the foreseeable future.

Fabius spoke in the preparation for the 1992 regional and cantonal elections of the need to work with the Mouvement des Radicaux de Gauche, France Unie, the two ecologist parties, the Communist renovators, other communists ... all those who form the Left and the progressives in the 1990s in all their diversity'. ${ }^{4}$ However, the offer of an early electoral pact foundered in the absence of structural changes to the electoral system to facilitate ecologist progress. ${ }^{5}$ The 'all-conquering' Greens were resolutely unimpressed by such offerings.

Fabius may have overestimated PS strength, or lacked the strategic vision to see the possibilities of a left-Green alliance. Perhaps he was reluctant to contemplate changes to the electoral system which would have the epiphenomenal effect of advancing the FN's cause. Fabius nonetheless played his hand badly. He attempted to repair bridges by 'greenwashing' the party's discourse,${ }^{6}$ then took the extraordinary step of deciding to withdraw unilaterally from second-round ballots in seats where the ecologists were ahead after the first, despite a lack of any electoral pact (Boy, 1993: 164-5). After this abject failure, Mauroy attacked Fabius and held the courant system responsible for the ill-adapted electoral strategy of 1993 . 'The courants ... made us forget a realistic and adapted strategy ... We refused to understand that the only possible dialogue with the ecologists had to start with the adoption of a mixed electoral system, responding to the demands of democracy given the new political configuration.' 7

Whether Mauroy would have handled things any differently, had he remained First Secretary a little longer, we will never know. The point, however, is that the intra-party debates over relations with electoral allies dealt with issues of such fundamental importance to the operation of the French party system as whether or not an offer of electoral system reform should have been made to the ecologists. Had Mauroy, not Fabius, presided over the negotiations, the shape of the French party system might be very different. If the smaller political movements of the left in 
all its diversity could have been brought under the same umbrella, could the catastrophic defeat of 1993 been avoided? Probably not, but the PS might have avoided plummeting quite as low as it did. The overall vote polled by the ecologist movements was 10.8 per cent in 1993 . Had the PS been able to count on some of that support in the second ballot, it could have drastically reduced the scale of its defeat.

Episode 2: Rocard's 'big bang' - the attempted restructuring of the French party system

In the wake of the crushing defeat of French Socialism, the PS's relationship with the French party system underwent a series of fairly rapid changes. In order to understand fully the shifts in direction and rationale which ensued, we must look to the ascendancy or otherwise of various factional groupings. Fabius resigned, leaving his factional rival Rocard with scope to redesign the party's electoral strategy. Rocard's proposed big bang claimed to tap into secular changes within the French electoral context. The big bang sought to take account of the changes both in voting behaviour and the socio-economic structure of society. This was an electoral strategy designed to work in the context of what Gérard Le Gall, the PS chief electoral strategist, has called 'sociological quasiindeterminism' (1993). Heightened electoral volatility and the declining relevance of socio-economic position to voting behaviour, had been factored in to Rocard's analysis.

The PS would, he hoped, ride the waves of these changes, and herald a restructuring of the French party system. Having criticised PS's traditional 'submission' of its allies, Rocard envisaged a 'vast movement, open, modern and rich in its diversity, ... [which] will encompass the reformism of ecologists, the loyalty to a social tradition of centrisme, and the authentic renovatory impulse of communism.' To facilitate the construction of this movement, Rocard advocated institutional changes to the French party system. 'Attached as I am to the majoritarian system, I think it indispensable to add to it a dose of proportional representation into the present system', Rocard implored all concerned to confront the obstacles to 'the political big bang to which I aspire' ${ }^{8}$ Rocard's radical project caused a stir, not least because it seemed to threaten the end of the PS. Rocard was proposing a rééquilibrage - redesigning the political landscape and reinventing existing political parties (Charlot, 1994: 270). The explicit advocacy of alliances with the centre had long been the Rocardian political strategy of choice, but his conversion to electoral reform gave the big bang a novel air.

In 1993, Rocard's position as both president of the party and candidat naturel for the presidency suggested that a rééquilibrage along these lines could have been possible. However, Rocard's idea never really weathered the storm that followed the 1993 defeat. The centrists firmly associated 
themselves with the parties of the right, some joining the Balladur government, others dissolving their own parliamentary group. Thus the realignment was only likely to happen within the left, since the centrists had raised the drawbridge. However, even this smaller-scale realignment was hampered. The spectacular failure of Rocard's gamble is largely explained by intra-party fighting, and the ongoing factionalism within the PS. Mitterrand was determined to derail Rocard's big bang, ${ }^{9}$ part of his implacable opposition to Rocard's bid to succeed him as President. Mitterrand's friends within the Party accordingly backed Tapie's Energie Radicale list in the 1994 European elections against Rocard's official list. This split in the left vote helped the PS list plummet below 15 per cent - a humiliating result even given the PS's very low expectations in the wake of 1993 .

Even before the European election results finally destroyed Rocard's political credibility, however, his intended redrawing of the political landscape was not proceeding entirely as he envisaged. Competing factional visions endured within the PS over the party's point of insertion into the French party system, who were the best allies, and on what ideological territory to meet them. Rocard's ambition for the Assises de la transformation sociale, a set of meetings with all potential allies, and supposedly the first institutional manifestation of the big bang in action, was to approach civil society groups and centrists. While Rocard happily involved Communist 'renovators' such as Herzog, he did not aim to reconstruct the union de gauche. However, those organising the Assises Jospin, a disciple of mitterrandiste political strategy, and Cambadélis, a one-time Trotskyist and loyal Jospin ally - did not share Rocard's strategic vision.

Although marginalised in the party and contemplating leaving politics at the time, Jospin saw the Assises as an ideal opportunity to explore the potential of the Rouge-Rose-Vert coalition. Rocard became aware that the direction being taken by the Assises deviated from his vision, but Rocard's lack of a hegemonic position within the PS analogous to that enjoyed by Mitterrand when steering the party's political strategy in the 1970s meant that he could not impose his vision. Furthermore, Rocard's lack of hegemonic authority within the party was mirrored by the PS's lack of hegemonic authority on the left of the French party system. Fabius's experiences with the Greens prior to 1993 indicated that the PS elite was no longer at liberty to dictate the terms of relations with competitor formations. In the period 1993-94, articles in the PS weekly Vendredi on electoral strategy contain the disclaimer, in the spirit of partnership, exempt from any desire for hegemony, and respecting the autonomy of each formation'. ${ }^{10}$

How genuine this newfound modesty really was is questionable, but it nevertheless hints at a real impediment to the desired restructuring 
process. The PS did not seem the appropriate body to orchestrate the rééquilibrage because it was too tarnished and powerless a body to deliver on any pacts it formed with other political formations, not least because changing the electoral system requires being in government. Both internally within the party, and externally within the party system, Rocard was not in a position to deliver his big bang. Indeed, the late Pierre Guidoni argued that bargaining only really began from a position of relative strength, in the wake of Jospin's creditable 1995 presidential election defeat, which was a necessary precondition of re-establishing alliances. 'In reality, we pursued our alliance strategy only when we regained electoral hegemony, it was at that moment that we could start offering presents.' 11

\section{Episode 3: The birth of the gauche plurielle}

Internally, the context of factionalism changed after 1995, when the prize everyone was fighting for - the presidency - was lost. Jospin ended 1995 as defeated presidential candidate, but also the unassailable leader of the left in France. Jospin converted his political capital gained by his 'successful' defeat into security of tenure and an hegemonic position within the PS by becoming (before the process had reached the party's statute book) the first directly elected PS first secretary (Clift, 2000). At that point, just as had happened earlier under Mitterrand, a ceasefire descended, making coordination of electoral strategy much easier. In stark contrast to the early 1990s, once Jospin's internal (and external) ascendancy was assured, his hands were freed to proceed as he wished in shaping PS electoral strategy.

In hindsight, the Assises de la transformation sociale in 1993-94 constituted vital groundwork which paid dividends when Jospin was re-elected first secretary. The four programmatic conventions under Jospin, and the programmatic elements for the meetings with the PCF and the ecologists, were all traceable back to the Assises. The dynamic of recovery set in train by 1995 heralded a renovation, with significant modifications, of the union de gauche. In its rassemblement of the whole of the left, Jospin's political strategy displayed some Mitterrandist continuity, but, with the addition of the Greens, the gauche plurielle represented a novel structuration of the French party system.

Within the PS, Jospin's internal hegemony represented an enormous asset in dealings with potential allies. Jospin's orchestration of candidate designation (a process facilitated by the haste-inducing surprise dissolution) for the 1997 legislative elections leaving room for alliance candidates clearly demonstrated this. The trick was to 'organise the legislative elections as if they were proportional elections'. ${ }^{12}$ This attested to a degree of centralised organisation which, as Rocard found, is difficult to achieve when the de facto leader of the party does not enjoy widespread support 
within the party. The spectacular failure of Hollande's gauche unie in June 2002 can be traced in part to his lack of his internal hegemony analogous to Jospin's. Protracted, ill-tempered PS-PCF-Verts-PRG electoral negotiations eventually achieved only 34 single candidacies, not the 577 that Hollande had hoped for, with an additional 136 'partial agreements' involving a candidate 'wearing the colours' of at least two of the four formations at the first ballot. ${ }^{13}$

Internal developments within the PS's ally formations were also important preconditions of the gauche plurielle. This point, which further highlights the importance of analysing intra-party politics when considering party system change, can be illustrated by briefly considering the case of the Greens and the PCF. In the mid-1990s, Voynet and Cochet overcame internal opposition, and the Greens emerged as the dominant force in French political ecology (O’Neill, 1997: 195-209). Under Voynet's direction, the Greens came to abandon their 'neither right nor left' stance in the face of electoral difficulties at grass-roots level. The modest performance in the 1994 cantonals, no seats in the European elections, and the difficulties they had fielding candidates on a national level ${ }^{14}$ further underlined what Daniel Boy (1993) has termed the 'coming back down to earth' of the ecologists in the period after 1993. The eschewal of all alliances contradicted the institutional logic of the system. When only Dominique Voynet made it to the second ballot of the 1993 legislative elections, these difficulties were brought home to the Greens.

With PS recovery after 1995, the Greens realised there was no longer the political space available. This very different political context, facilitated, prior to 1997, the first alliance being concluded between the PS (supporting 29 Green candidates) and the Greens (supporting 77 PS candidates). In terms of structural changes, Jospin made encouraging noises about PR to woo the Greens. In 2002, four of the single gauche unie candidacies were Green, and the PS supported 59 Green candidates (albeit in safe right seats), who in turn supported 94 Socialists. Despite increased Green first-round vote share (from 3.6 per cent in 1997 to 4.5 per cent), the vagaries of the electoral system left them with only three deputies.

The significant developments in the PCF's internal politics were threefold: ongoing decline, the increasing importance and autonomy of the PCF 'red' notables, and the change of leadership. The PCF's continuing decline shifts the terms of trade against the PCF, reducing its room to manoeuvre (despite the surprisingly resilient return of 21 deputies in June 2002). Second, as David Bell has noted in this volume (Chapter 2), local politics has become of increasing importance to the PCF as it declines nationally. The need to retain 'political reality' at the local level constrains the PCF at the national level, due to the autonomy which local notables derive from their local power bases and consequently allows 
them to pave the way in areas where alliance is mutually advantageous, for closer PS-PCF cooperation. Thus the PCF is condemned to the Union.

Third, with the arrival of Robert Hue some foresee a steady reduction in the distance between the two historic rivals. Such predictions paper over certain significant cracks - the pace of reforms and European policy, for instance, not to mention the legacy of eighty years of hostility. Nevertheless, the PCF has few other strategic options, beyond a dangerous radicalisation which, as Bell has also noted in this volume (Chapter 2), could result in the destruction of the left's electoral coalition. As a result of partial 'social democratisation' under Hue, and the shifting terms of trade in the Socialists' favour, the fundamental differences which produced the deux cultures have dissipated as the price to pay for union with the PCF reduced.

\section{Conclusion}

Early in the 1990s, the PS attempted root-and-branch restructuring both of itself and the French party system. The restructuring failed, for both external reasons, in the form of adverse electoral results, and internal reasons, namely the falling from grace of the strategy's key proponent, or the sabotage of the strategy by factional rivals. The success of Jospin's post-1995 restructuring owes a great deal to the fact that, internally, despite recent structural changes, the basic institutional logic which once underpinned Mitterrand's dominance of the party underpinned Jospin's incontournable position within the PS. Furthermore, externally, a similar strategic vision which once inspired the union de gauche, rooted in the 'institutional cement' of the rules of the game of the French party system, was seen by Jospin as a sine qua non of political success and underpinned the gauche plurielle.

The gauche plurielle owed a great deal both to Jospin's internal hegemony, and to the reestablishment of PS electoral hegemony on the left. The 2002 defeats may reopen debates about increased proportionality, which could fundamentally alter the institutional logic which cemented the gauche plurielle, creating uncertainty about the future shape of, and strategies within, the left pole of the French party system. The first attempt at a successor strategy, the gauche unie, proved incompatible with the institutional logic of dual-ballot elections, and failed given record abstention, the continued decline of the PCF, disappointing results for the Greens and increased fragmentation of the left, which could not agree to cohere around a damaged but still dominant PS. In its wake, it is unclear whether the conditions exist to rebuild a governing coalition of the left within the French party system. 


\section{Notes}

1 Set at 5 per cent of those voting in 1958, revised to 10 per cent of the registered electorate in 1966, which was in turn raised to 12.5 per cent of the registered electorate in 1976.

2 The proportional list elections (regional, European) involve a high degree of central input into list construction. For cantonal and municipal elections candidate selection is, on the whole, decided at the section level. For parliamentary elections, candidate selection takes place at the departmental or federation level, where the degree of national-level interference also varies (see below).

3 The strength of any given courant is determined by the votes its motion receives. The bottom line is a mathematical equation between proportion of votes obtained and proportion of internal positions of responsibility. The federal structures mirror the national, where, at the departmental level, all factions are represented proportionately on the Federal Executive (Bell and Criddle, 1988: 210-16 and Figure 10.1).

4 PS Info no. 512 (18 April 1992) - proceedings of the Comité Directeur 12 April 1992.

5 In part as a means to appease the Greens, the multi-party Vedel Commission had been convened in 1992 to look at electoral reform, ultimately recommending a compromise position of a mixed AMS (German-style) system, with 10 per cent of National Assembly seats decided proportionally. Prime Minister Bérégovoy (a close associate of Fabius) decided not to proceed with electoral reform ahead of the 1993 elections.

6 Fabius claimed Bérégovoy's government was engaged in a model of growth he called 'eco-development ... nothing less than an ecological restructuring of society' Journal Officiel de l'Assemblee Nationale, 8 April 1992, p. 381.

7 PS Info no. 544 (17 April 1993) - proceedings of the Comité Directeur, 3 April 1993.

8 All quotes taken from Rocard's speech at Montlouis-sur-Seine, 17 February 1993.

9 Despite personally favouring a shift to proportional representation, for example in the 1993 elections (Favier and Martin-Roland, 1991: 266, 383).

10 See. e.g., La Lettre de Vendredi no. 31, 21 October 1994; communiqué commun PS/PCF 18 October 1994.

11 Interview with Pierre Guidoni, PS National Secretary for International Relations, 24 September 1997.

12 Ibid.

13 The PS agreed to withdraw from 105 constituencies, 13 in favour of the PCF and 33 in favour of the PRG. In exchange, the Socialists benefited from Communist support in 36 constituencies, and from the PRG in 515 constituencies. Of the 34 single candidacies, 14 were PS, 12 were PCF, 4 PRG and 4 Greens (Libération, 18 May 2002).

14 Only 37 per cent of constituencies had a green candidate in the cantonal elections, and they gained only 3.9 per cent of the vote. 